www.jmscr.igmpublication.org

Impact Factor 5.84

Index Copernicus Value: 71.58

ISSN (e)-2347-176x ISSN (p) 2455-0450

crossref DOI: _https://dx.doi.org/10.18535/jmscr/v5i9.101

Journal Of Medical Science And Clinical Research

\title{
Comparative Evaluation of diagnostic performance of Blood culture, Lateral flow immunoassay, Tube Widal and Slide Widal Test in diagnosis of Enteric fever using a Composite Reference Standard
}

\author{
Authors \\ Abhishek Mehta ${ }^{1 *}$, Devesh Sharma ${ }^{2}$, Vijay Prakash Singh ${ }^{3}$ \\ 1,2,3 Department of Microbiology, KD Medical College, Hospital \& Research Center, \\ NH\#2, 24Km. milestone, Akbarpur (Uttarpradesh), Distt.Mathura, India-281406 \\ *Corresponding Author \\ Dr Abhishek Mehta
}

Flat-102, Staff quarters, GL Bajaj Instt. campus, 24Km.milestone, NH\#2, Akbarpur (Uttarpradesh),

Distt. Mathura, India-281406

Phone No: +91-9897620394, Email: abhishekmehta623@gmail.com

\begin{abstract}
Background: Enteric fever a potentially fatal multi systemic infectious disease is well recognised as a serious public health problem throughout the world. Undiagnosed and untreated cases may result in serious complications. Prompt and accurate diagnosis of the cases is the most important step for the efficient timely management of the disease.

Aim: to compare and evaluate the diagnostic performance of various diagnostic modalities for Enteric fever like Blood culture,Tube widal, Slide widal and Typhoid IgG/IgM Rapid Card test using a Composite Reference standard.

Material and Methods: This cross sectional analytical study was conducted in the Dept.of Microbiology of a rural tertiary care teaching hospital of western Uttarpradesh, India from July 2016 to June 2017 over a period of one year after obtaining permission from the institutional ethics committee.

Blood culture was done using standard microbiological techniques. Slide widal, Tube widal \& Typhoid IgG/IgM Rapid Card tests were done as per instructions in the kit insert. Various diagnostic parameters like Sensitivity, Specificity, Positive Predictive Value, Negative Predictive Value, Accuracy, Positive Likelihood ratio and Negative Likelihood ratio for all the tests were calculated and compared using a Composite Reference standard.

Results: In this study the overall positivity rate for Blood culture was 12\%, Tube Widal 32\%, Slide Widal 46\% and IgG/IgM RCT 48\%. Amongst all four diagnostic tests under study highest sensitivity was exhibited by IgG/IgM RCT (77.42\%) and highest specificity was observed for Blood culture(100\%)

Conclusion: Amongst all the tests evaluated in this study IgG/IgM Rapid card Test which is a fast, reliable, simple and easy to perform test had emerged as the best diagnostic modality for appropriate and timely management of enteric fever.

Keywords: Enteric Fever, Blood culture, Widal test, Typhoid IgG/IgM Rapid Card test, Lateral flow immunoassay, Composite Reference Standard.
\end{abstract}




\section{Introduction}

Enteric fever is well recognised as a serious public health problem throughout the world. As per the WHO records the global annual incidence of Enteric Fever is about 20 million cases with greater than 6 Lac deaths reported annually. ${ }^{1,2}$

Enteric Fever is mainly encountered in developing countries of South East Asia including India which accounts for almost $80 \%$ of the total worldwide cases. ${ }^{3,4}$

Enteric fever is a potentially fatal multi systemic infectious disease caused primarily by Salmonella enterica subsp. enterica serovar typhi and to a lesser extent by Salmonella paratyphi A,B \& C. - $^{5-7}$ The main factors contributing towards this public health problem are rapid population growth, increasing urbanisation, contaminated water supply, poor hygiene and lack of sanitation. ${ }^{1,5,8}$ In such community settings, the other causes of febrile illness exist like malaria, dengue, rickettsiosis, leptospirosis and meliodosis. These illnesses are not easily distinguishable esp. in the initial stage and hence creates confusion in clinical diagnosis. Undiagnosed and untreated cases may result in serious complications. ${ }^{5,9}$

Prompt and accurate diagnosis of the cases is the most important step for the efficient management and control of the disease.

Bone marrow culture and Blood culture have been recognised as the Gold standard diagnostic modalities in Enteric fever. Although cutures are more reliable but not that simple and easy to perform and are expensive and time consuming requiring infrastructure, equipments \& trained Laboratory staff that is seldom available in resource constrained remote settings of developing countries. $5,6,10$

So, in most of these countries, widal test is the most preferred diagnostic modality for enteric fever as it is cost effective, simple, easy and does'nt require much training and resources ${ }^{[11]}$. But there is always a lack of uniformity in the interpretation of results as significant titre varies in different regions and in different community settings and also influenced by other co-existing factors. However it is useful only in second week of illness and paired sera required for confirmation of result. ${ }^{1,11,12}$

Widespread, inappropriate, indiscriminate and irrational use of antibiotics prior to sample collection is the biggest obstacle in isolation of causative organism in bacterial cultures and also contribute in the emergence of multi drug resistant strains. $^{6,10,13}$

So, there is always a need for a fast, reliable, simple and easy to perform sero-diagnostic test with a higher sensitivity and specificity than the conventional modalities for appropriate and timely management of enteric fever. Prompt and accurate diagnosis of enteric fever cases at early stage helps in identifying persons who may turn as potential carriers and can lead to outbreaks. ${ }^{1,11,14}$

Typhoid IgG/IgM Rapid card test is a Lateral flow Immunochromatographic test. It detects presence of $\operatorname{IgM}$ and $\operatorname{IgG}$ antibodies to S.typhi and S.paratyphi lipopolysaccharides. It could be used as a rapid screening test for Enteric fever as early as in first week of the febrile illness. The test is easy to perform and results can be interpreted visually within 15 minutes.So,nowadays such immunoassays are emerging as preferred alternative for rapid and easy diagnosis of Enteric fever. ${ }^{11}$

So, we had underataken this cross sectional study to compare and evaluate the diagnostic performance of various diagnostic modalities for Enteric fever like Blood culture, Tube widal, Slide widal test and Typhoid IgG/IgM Rapid Card test using a Composite Reference standard.

\section{Materials and Method}

This cross sectional analytical study was conducted in the Dept.of Microbiology of a rural tertiary care teaching hospital of western Uttarpradesh from July 2016 to June 2017 over a period of one year after obtaining permission from the institutional ethics committee. The samples collected from the clinically suspected cases were processed as a part of standard diagnostic protocol. All the diagnostic tests evaluated in the 
study were part of the routine diagnostic procedures and not meant exclusively for the research purpose. Only the diagnostic performance of these tests were compared. Personnel data regarding patients was not used for the research and was kept confidential.

\section{Inclusion criteria ${ }^{2,6,11}$ - A total of 100 clinically} suspected cases of Enteric fever irrespective of age \& sex presenting with any signs \& symptoms suggestive of Enteric fever like:

$>$ History of fever $>3$ days

$>$ Abdominal discomfort, constipation or loose motion

$>$ Coated tongue

$>$ Toxic look, hepatomegaly, Spleenomegaly, rose-spots

Relative bradycardia, etc.

were included in the study by simple random sampling.

\section{Exclusion criteria ${ }^{2,5-7,11}$}

$>$ The patients with any other known cause of febrile illness other than Enteric fever.

$>$ Repeat samples

$>$ Patients with a history of prior antibiotic therapy and/or

$\mathrm{H} / \mathrm{O}$ Typhoid vaccination in recent past; were excluded from the study.

\section{Sample collection ${ }^{5,11,15,16}$}

Venous Blood samples $10 \mathrm{ml}$ from adults and $5 \mathrm{ml}$ from children were collected aseptically and inoculated into Adult \& Paediatric blood culture bottles containing BHI Broth with SPS (Microexpress, India) respectively.

Another $3 \mathrm{ml}$ blood was collected in sterile plain vial and allowed to clot. Serum separated was used for Widal test and Rapid Card test(Lateral Immunoflow assay).

\section{Blood Culture/Sensitivity}

The inoculated blood culture bottles with blood to broth ratio 1:10 were incubated aerobically at $37^{0} \mathrm{C}$ for $24 \mathrm{hrs}$.
Subcultures were made on blood agar and MacConkey agar plates every alternate day till $7^{\text {th }}$ day. Bacterial colonies grown over the culture plates were further processed using standard microbiological techniques. Isolation, Identification and characterisation of Salmonella sp. was done as per standard protocol through biochemical tests followed by Slide agglutination using antisera. ${ }^{5,12,15-20}$

Antimicrobial susceptibility testing was performed for all isolates using Kirby Bauer Standard Disc diffusion method as per CLSI 2016 guidelines. ${ }^{21}$

Widal test: Widal test was performed by tube method and Slide method both. ${ }^{2,6,8,11,13,19}$

Widal Tube Agglutination test was performed using Febrile Antigen Set (Arkay Healthcare, Surat, India).

Widal Slide test (Latex agglutination test) was performed using Widal antigen set (Tydal antigen suspension, Tulip diagnostics, Goa,India).

Test procedures were performed as per manufacturer's instructions given in the kit insert.

Interpretation of Widal test: Widal test irrespective of the method employed was interpreted as positive for a titre of $>80$ for $\mathrm{O}$ agglutinins and a titre of $>160$ for $\mathrm{H}$ agglutinins based on the prevailing basal titres in that region and in that community settings as being evaluated prior to the commencement of the study.

\section{Typhoid IgG/IgM Rapid Card Test ${ }^{11,14}$}

Typhoid IgG/IgM Rapid Card Test(CTK Biotech, San Diego. CA) is a Lateral flow immunochromatographic test for qualitative detection and differentiation of $\operatorname{IgG}$ and $\operatorname{IgM}$ anti- S.typhi and anti- S. paratyphi antibodies in the test serum.

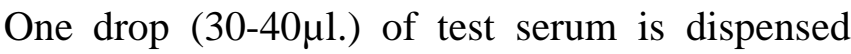
into the sample well of test device followed by one drop of sample dilluent/buffer. Results were read within 15 minutes.

\section{Interpretation:}

1) Negative/Non-reactive result: If only $\mathrm{C}$-band is present(pink/purple line in control region) with no band in both the test regions $M$ \& G(regions 
specifying $\operatorname{IgM} \&$ IgG respectively) indicates Negative result.

2) Positive/Reactive result: C-Band must be present and in addition to it if

a) Only $M$ band is present, the result is $\operatorname{IgM}$ positive.

b) Only G-band is present then the result is IgG positive.

$\mathrm{C}$ )Both $\mathrm{M}$ and $\mathrm{G}$ bands are present then the result is both $\operatorname{IgM} \& \operatorname{IgG}$ reactive/positive.

3) Invalid: If no C-band develops in the control region, the assay is considered invalid regardless of appearance of any band in the test region.

Test procedures and interpretation of results were done according to manufacturer's instructions in the kit insert.

A comparative evaluation of diagnostic performance of Blood Culture, Tube widal, Slide widal test and Typhoid IgG/IgM Rapid Card Test was done against a Composite Reference Standard using tests for statistical significance. ${ }^{5,12,22-24}$
The composite reference standard was based on the following criteria:

I) All the blood culture positive cases

II) Blood culture negative cases with the 2 tests positive out of the following 3 serodiagnostic tests:

1)Tube Widal Test

2)Slide Widal Test

3) $\operatorname{IgG} / \mathrm{IgM}$ Rapid Card Lateral flow Immunoassay.

Were considered as Composite Reference standard positive confirmed cases.

Statistical analysis: Various diagnostic parameters like Sensitivity, Specificity, Positive Predictive Value, Negative Predictive Value, Accuracy, Positive Likelihood ratio and Negative Likelihood ratio for all the tests were calculated and compared. The statistical analysis of results was done to establish the test of significance (Mc Nemar's Chi square test) for clear and confirmatory statements. p-value $<0.05$ was considered statistically significant. ${ }^{13,25}$

Table-1: Composite Reference Standard Positive Cases of Enteric Fever

\begin{tabular}{|c|c|c|}
\hline S.No & Diagnostic Test & $\begin{array}{l}\text { Composite-Reference } \\
\text { Standard Positive Cases }\end{array}$ \\
\hline A. & Blood Culture Positive cases & 12 \\
\hline 1. & RCT only & 4 \\
\hline 2. & $\mathrm{RCT}+\mathrm{SW}$ & 1 \\
\hline 3. & $\mathrm{RCT}+\mathrm{TW}$ & 5 \\
\hline 4. & $\mathrm{RCT}+\mathrm{SW}+\mathrm{TW}$ & 2 \\
\hline B. & Blood Culture Negative cases & 50 \\
\hline 1. & $\mathrm{TW}+\mathrm{SW}$ & 8 \\
\hline 2. & $\mathrm{TW}+\mathrm{RCT}$ & 13 \\
\hline 3. & $\mathrm{SW}+\mathrm{RCT}$ & 21 \\
\hline \multirow[t]{2}{*}{4.} & $\mathrm{TW}+\mathrm{SW}+\mathrm{RCT}$ & 2 \\
\hline & Total $(\mathrm{A}+\mathrm{B})$ & 62 \\
\hline
\end{tabular}

Table-2: Laboratory test Results in correlation with the duration of illness

\begin{tabular}{|l|c|c|c|c|c|}
\hline Duration of $\begin{array}{c}\text { Number of } \\
\text { illness in weeks }\end{array}$ & \multirow{2}{*}{$\begin{array}{c}\text { Nug. Test +ve } \\
\text { Diases }\end{array}$} & \multicolumn{4}{|c|}{ Diagnostic Test Positive cases } \\
\cline { 3 - 6 } & & Blood culture & Tube Widal & Slide Widal & RCT \\
\hline $1^{\text {st }}$ & 30 & 10 & 2 & 3 & 20 \\
\hline $2^{\text {nd }}$ & 54 & 2 & 23 & 30 & 25 \\
\hline $3^{\text {rd }}$ & 16 & 0 & 7 & 13 & 5 \\
\hline Total & 100 & 12 & 32 & 46 & 50 \\
\hline
\end{tabular}


Table-3: Diagnostic Test Characteristics of Laboratory Tests for Enteric Fever

\begin{tabular}{|c|c|c|c|c|c|c|c|}
\hline $\begin{array}{l}\text { Diagnostic } \\
\text { Test }\end{array}$ & $\begin{array}{c}\text { Sensitivity } \\
95 \% \text { CI }\end{array}$ & $\begin{array}{c}\text { Specificity } \\
95 \% \text { CI }\end{array}$ & $\begin{array}{c}\text { PPV } \\
95 \% \mathrm{CI}\end{array}$ & $\begin{array}{c}\text { NPV } \\
95 \% \mathrm{CI} \\
\end{array}$ & $\begin{array}{l}\text { Accu } \\
\text { racy }\end{array}$ & $\begin{array}{c}{ }^{+} \mathrm{LR} \\
95 \% \mathrm{CI}\end{array}$ & $\begin{array}{c}-\mathrm{LR} \\
95 \% \mathrm{CI} \\
\end{array}$ \\
\hline $\begin{array}{l}\text { Blood } \\
\text { Culture }\end{array}$ & $\begin{array}{c}19.355 \\
(10.42 \%- \\
31.37 \%)\end{array}$ & $\begin{array}{c}100 \\
(90.75 \%- \\
100.00 \%)\end{array}$ & 100 & $\begin{array}{c}43.2 \\
(40.22 \%- \\
46.20 \%)\end{array}$ & 50 & - & $\begin{array}{c}0.81 \\
(0.71-0.91)\end{array}$ \\
\hline $\begin{array}{l}\text { IgG/IgM } \\
\text { RCT }\end{array}$ & $\begin{array}{c}77.42 \\
(65.03 \%- \\
87.07 \%\end{array}$ & $\begin{array}{c}94.74 \\
(82.25 \%- \\
99.36 \%)\end{array}$ & $\begin{array}{c}96 \\
(86.09 \%- \\
98.94 \%)\end{array}$ & $\begin{array}{c}72 \\
(61.72 \%- \\
80.40 \%)\end{array}$ & 84 & $\begin{array}{c}14.7 \\
(13.79- \\
57.06)\end{array}$ & $\begin{array}{c}0.24 \\
(0.15-0.38)\end{array}$ \\
\hline Tube Widal & $\begin{array}{c}48.39 \\
(35.50- \\
61.44 \%)\end{array}$ & $\begin{array}{c}94.74 \\
(82.25 \%- \\
99.36 \%)\end{array}$ & $\begin{array}{c}93.75 \\
(79.16 \%- \\
98.34 \%)\end{array}$ & $\begin{array}{c}52.94 \\
(46.6 \%- \\
59.15 \%)\end{array}$ & 66 & $\begin{array}{c}9.1935 \\
(2.33-36.30)\end{array}$ & $\begin{array}{c}0.545 \\
(0.42-0.70)\end{array}$ \\
\hline Slide Widal & $\begin{array}{c}55 \\
(41.68 \%- \\
67.52 \%)\end{array}$ & $\begin{array}{c}68.42 \\
(51.35 \%- \\
82.50 \%)\end{array}$ & $\begin{array}{c}74 \\
(62.76 \%- \\
82.65 \%)\end{array}$ & $\begin{array}{c}48 \\
(39.57 \%- \\
56.83 \%)\end{array}$ & 60 & $\begin{array}{c}1.74 \\
(1.03-2.92)\end{array}$ & $\begin{array}{c}0.66 \\
(0.47-0.94)\end{array}$ \\
\hline
\end{tabular}

Table-4: Comparative assessment of diagnostic tests with reference to CRS

\begin{tabular}{|l|c|c|c|c|c|c|}
\hline \multirow{2}{*}{ Test } & \multicolumn{3}{|c|}{ Result } & \multicolumn{2}{c|}{$\begin{array}{c}\text { Mc Nemar's } \\
\text { Chi-square Test }\end{array}$} & p-Value \\
\cline { 2 - 6 } $\begin{array}{l}\text { Reference } \\
\text { Standard }\end{array}$ & RF +ve & RF-ve & RF +ve & RF -ve & & \\
\hline Blood culture & 12 & 0 & 50 & 38 & 48.02 & 0 \\
\hline $\begin{array}{l}\text { Tube Widal } \\
\text { Test }\end{array}$ & 30 & 2 & 32 & 36 & 24.735 & 0 \\
\hline $\begin{array}{l}\text { Slide Widal } \\
\text { Test }\end{array}$ & 34 & 12 & 28 & 26 & 5.625 & 0.00885 \\
\hline $\begin{array}{l}\text { IgG/IgM } \\
\text { RCT }\end{array}$ & 48 & 2 & 14 & 36 & 7.682 & 0.0028 \\
\hline
\end{tabular}

\section{Results and Discussion}

In this study we had found that out of the total 100 clinically suspected cases of Enteric fever, blood culture came out to be positive in only 12 cases all of which were Salmonella enterica serotype typhi. As evident by a number of studies conducted in the recent past, a very low blood culture positivity rate was seen in clinically suspected cases of Enteric fever. Due to its limited sensitivity and higher specificity it could not be practically considered as a Reference Gold standard. So, an alternative Composite reference standard was designed for this study. Such reference standards were previously been used in a number of studies involving the comparison of diagnostic tests(Baughman AL et al $2008^{23}$, Siba V et al $2012^{12}$, Naaktgeboren CA et al $2013^{22}$, Mitra S et al $2016^{24}$,Maheshwari $\mathrm{V}$ et al $2016^{5}$ ).

Out of 100 clinically suspected cases of Enteric fever, a total of 62 cases fulfilling the criteria of the Composite Reference standard and accordingly considered as confirmed cases of Enteric fever, included in Reference standard positive category and remaining 38 cases as Reference Standard negative [Table-1].

Highest positivity rate for Blood culture was found during first week of illness(83.3\%). In case of Tube Widal as well as Slide Widal most of the test positive cases were found to be reported in the $2^{\text {nd }}$ and $3^{\text {rd }}$ weeks of illness $(93.75 \%$ and $93.48 \%$ respectively). In case of IgG/IgM Rapid Card Test diagnostic utility was found significant during $1^{\text {st }}$ and $2^{\text {nd }}$ weeks of illness with $89.6 \%$ positive outcome [Table-2]. Similar observations were reported by Baragundi $M$ et al $2010^{26}$ and Maheshwari V et al $2016^{5}$.

In this study the overall positivity rate for Blood culture was $12 \%$, Tube Widal $32 \%$, Slide Widal $46 \%$ and $\mathrm{IgG} / \mathrm{IgM}$ RCT $48 \%$. The low isolation rate in case of Blood culture may be due to a number of factors like prior antibiotic therapy, inadequate volume of blood inocula and late presentation (Maheshwari V et al $2016^{5}$, Sharanya $\mathrm{K}$ et al $2016^{11}$, Mohanty SK et al $2007^{27}$ ). A number of studies in the past have reported low isolation rates for blood culture (Sharanya $\mathrm{K}$ et al 
$2016^{11}$, Porwal A et al $2016^{28}$, Poudel $\mathrm{S}$ et al $2014^{29}$,Yadav $\mathrm{S}$ et al $2014^{30}$, Bargundi $\mathrm{M}$ et al $2010^{26}$ ). Mohanty \& Ramana $2007^{27}$ attributed the relative low sensitivity of the blood culture in diagnosing Enteric fever due to widespread and irrational use of antibiotics and insufficient volume of blood collection from paediatric subjects.

In this study out of 100 samples tested Tube Widal came out to be positive in 32 cases and Slide widal in 46 cases. Sensitivity of Tube Widal came out to be $6.67 \%$ in first week of illness, $42.6 \%$ in second week and $43.75 \%$ in third week.

Sensitivity of Slide widal was $10 \%$ in first week, $55.56 \%$ in second week and $81.25 \%$ in third week. These findings are similar to study conducted by Sanjeev $H$ et al $2013^{10}$.Usually $O$ antibodies appear on $6^{\text {th }}$ to $8^{\text {th }}$ day and $\mathrm{H}$ antibodies on $10^{\text {th }}$ to $12^{\text {th }}$ day after disease onset which accounts for the same $^{19}$.

Out of 100 samples tested in this study $\operatorname{IgG} / \operatorname{IgM}$ Rapid Card Test gave positive results in 50 cases out of which 48 were reference standard positive. Amongst all four diagnostic tests under study highest sensitivity was exhibited by $\mathrm{IgG} / \mathrm{IgM}$ RCT $(77.42 \%)$ followed by Slide widal $(55 \%)$, Tube Widal(48.39\%) and least sensitivity by Blood culture (19.35\%). Amongst all the tests under study highest specificity was observed for Blood culture (100\%) followed by both Tube widal and $\operatorname{IgG} / \operatorname{IgM}$ Rapid card test exhibiting same specificity $((94.74 \%)$ and least specificity for Slide widal(68.42\%) [Table-3].

In this study Tube widal had scored over Slide widal in terms of Specificity $(94.74 \%$ and $78.95 \%$ respectively). These findings are in accordance with number of studies conducted in the past.(Willke et al 2002, Oslen et al $2004^{34}$, Das JC et al $2007^{33}$, Keddy KH et al $2011^{32}$, Gaikwad UN et al $2014^{31}$, Sood NK et al $2014^{7}$, Ramaraj R $2016^{8}$, Radhika R et al $2017^{13}$ ).

But in this study Tube widal test has slightly lower Sensitivity as compared to Slide widal test (48.4\% and 55\% resp.).This finding is in accordance with the studies conducted by Olsen et al $2004^{34}$, Indro Handojo et al $2004^{35}$, Gaikwad UN et al $2014^{31}$, Radhika R et al $2017 .^{13}$

As compared to Slide widal, Tube widal test with a much better Specificity, positive predictive value (PPV), Negative Predictive value(NPV), Positive Likelihood ratio $\left(\mathrm{LR}^{+}\right)$and Negative Likelihood ratio $\left(\mathrm{LR}^{-}\right)$and a comparable sensitivity has been proved to be much superior to Slide widal in terms of diagnostic performance [Table-3].

Likelihood ratios (LR) being independent of disease prevalence are always better than predictive values while quantifying and comparing diagnostic performance of different tests.

Positive LR shows how much more likely someone is to get a positive test if he/she has the disease, compared with a person without disease and vice versa for Negative LR.

Positive and Negative Likelihood ratios were highest for the Blood culture. Blood culture also has $100 \%$ specificity. This could be attributed to the design of Composite reference standard of which blood culture is an integral part.

IgG/IgM Rapid card test having comparatively high values of Sensitivity, Specificity, PPV, NPV and significant Likelihood $\operatorname{ratios}\left(\mathrm{LR}^{+} \& \mathrm{LR}^{-}\right)$had came out to be the best diagnostic modality for Enteric fever amongst all the tests evaluated in this study [Table-3].

Test Accuracy was also highest for IgG/IgM RCT followed by Tube widal and Slide widal which had almost same accuracy.

The difference in the findings of the diagnostic tests under study was found to be highly statistically significant as evident in Table- 4 .

Conclusion: Amongst all the tests evaluated in this study IgG/IgM Rapid card Test which is having comparatively higher values of Sensitivity and Specificity and which is a fast, reliable, simple and easy to perform test had emerged as the best diagnostic modality for appropriate and timely management of enteric fever.

This test should be considered as one of the most potential alternative to the long established Widal 
test. It could be used as a rapid screening test for Enteric fever as early as in first week of the febrile illness. However it could be used as a rapid screening test but can never replace the Blood culture as the antibiotic susceptibility testing is highly recommended in the current scenario with emerging threat of multi drug resistant strains.

\section{Disclosure}

Source of funding: This research did not receive any specific grant from funding agencies in the public, commercial, or not-for-profit sectors.

Conflict of interest: Authors declare that they have no Conflict of interest.

\section{References}

1. Mengist HM, Tilahun K. Diagnostic Value of Widal Test in the Diagnosis of Typhoid Fever: A Systematic Review. J Med Microb Diagn 2017 ;6: 248. doi:10.4172/2161-0703.1000248

2. Abd Elseed YHAE. Comparison between the Widal test and culturing technique in the diagnosis of enteric fever in Khartoum State, Sudan. African Journal of Bacteriology Research 2015;7(5):56-59. doi: 10.5897/JBR2015.0151

3. Sharvani R, Hemavathi, Dayanand DK, Shenoy P, Sarmah P. Antibiogram of Salmonella isolates: Time to consider antibiotic salvage. J Clin Diag Res 2016;10(5): 6-8. doi:10.7860/JCDR/2016/18102.7753

4. Ali A, Ali HA, Shah FH, Zahid A, Aslam $\mathrm{H}$, Javed B. Pattern of antimicrobial drug resistance of Salmonella typhi and paratyphi $\mathrm{A}$ in a teaching hospital in Islamabad.J Pak Med Assoc 2017;67(3):375-78

5. Maheshwari V, Kaore NM, Ramnani VK, Sarda S. A Comparative Evaluation of Different Diagnostic Modalities in the Diagnosis of Typhoid Fever Using a Composite Reference Standard: A Tertiary Hospital Based Study in Central India. J
Clin Diag Res 2016; 10(10): 1-4. doi: 10.7860/JCDR/2016/20426.8684

6. Jahan N, Khatoon R, Amrita, Mehrotra S, Kumar S. Comparative evaluation of Slide agglutination and Widal tube agglutination test in detecting enteric fever among patients attending a tertiary care hospital in North India. Int $J$ Res Med Sci 2016;4:4290-6.

7. Sood NK, Jain MM,Patel S, Mandalia A,Bhavsar HK. A Prospective Comparative Study of Semi-quantitative Tube Widal test \& Quantitative Tube Widal test. NJIRM 2014;5(6):73-77

8. Ramaraj R. Enteric fever - over diagnosis by slide widal test. Univ J Pre Para Clin Sci 2016;2(7):1-6

9. Chrispal A, Boorugu H, Gopinath KG, Chandy S, Prakash JA, Thomas EM, Abraham AM, Abraham OC, Thomas $\mathrm{K}$. Acute undifferentiated febrile illness in adult hospitalized patients: the disease spectrum and diagnostic predictors - an experience from a tertiary care hospital in South India. Trop Doct 2010; 40(4):230-4. doi: 10.1258/td.2010.100132.

10. Sanjeev H, et al. A systematic evaluation of rapid dot-EIA, blood culture and Widal test in the diagnosis of typhoid fever. NUJHS. 2013;3(1):21-24.

11. Sharanya K, Vinod K, Lakshmi K. Comparison of Widal and typhoid Immunoglobulin $\mathbf{M}$ and Immunoglobulin $G$ in rapid and early diagnosis of enteric fever.Asian J Pharm Clin Res 2016;9(3):243-46.

12. Siba V, Horwood PF, Vanuga K,Wapling J,Sehuko R,Siba PM,Greenhill R.Evaluation of Serological Diagnostic Tests for Typhoid Fever in Papua New Guinea Using a Composite Reference Standard. Clin Vaccine Immunol.2012;19(11):1833-37.

13. Radhika R, Subathra N.Comparison of tube widal test and slide widal test in the 
diagnosis of enteric fever. Int $\mathbf{J}$ Microbiol Res 2017;9(4):888-90.

14. Prasad KJ, Oberoi JK, Goel N, Wattal C. Comparative evaluation of two rapid Salmonella IgM tests and blood culture in the diagnosis of enteric fever. Ind $\mathrm{J}$ Med Microbiol 2015;33(2): 237-242.

15. Balakrishna T, Sumathi S, Anuradha. K, Venkatesh D, Krishna S. A comparative study of typhidot and widal test in the diagnosis of typhoid fever. J evol med dent sci 2013; 2(21): 3720-25.

16. Singh VP , Mehta A. Bacteriological profile of blood stream infections at a Rural tertiary care teaching hospital of Western Uttar Pradesh. Ind J Bas App Med Res 2017;6(3):393-401

17. Collee JG, Marr W(2006) Culture of Bacteria. In: Collee JG, Fraser AG, Marmion BP, Simmons A (ed) Mackie \& McCartney Practical Medical Microbiology. $14^{\text {th }} \quad$ edn. Churchill Livingstone, London, pp 113-129.

18. Collee JG, Miles RS, Watt B (2006)Tests for the identification of bacteria. In: Collee JG, Fraser AG, Marmion BP, Simmons A (ed) Mackie \& McCartney Practical Medical Microbiology. $14^{\text {th }}$ edn. Churchill Livingstone, London, pp131-149.

19. Old DC(2006) Salmonella. In: Collee JG, Fraser AG, Marmion BP, Simmons A (ed) Mackie \& McCartney Practical medical microbiology. 14th ed. Edinburg: Churchill Livingstone; 2006. pp. 385-404.

20. Koneman E, Allen S, Janda W, Schreckenberger P, Winn W. Koneman's Color Atlas and Textbook of Diagnostic Microbiology. 5th ed. New York: Lippincott; 1997. pp. 251-58.

21. CLSI. Performance Standards for Antimicrobial Susceptibility Testing. 26th ed. CLSI supplement M100S. Wayne, PA: Clinical and Laboratory Standards Institute; 2016.
22. Naaktgeboren CA, Bertens LCM, Smeden M, Groot JA, Moons KGM, Reitsma JB. Value of composite reference standards in diagnostic research. BMJ. 2013; 347:f5605.

23. Baughman AL, Bisgard KM, Cortese MM, Thompson WW, Sanden GN, Strebel PM. Utility of composite reference standards and latent class analysis in evaluating the clinical accuracy of diagnostic tests for pertussis. Clin. Vaccine Immunol. 2008;15(1):106-14.

24. Mitra S, Choudhari R, Nori H, Abhilash KPP, Jayaseelan V, Abraham AM et al. Comparative evaluation of validity and cost-benefit analysis of rapid diagnostic test (RDT) kits in diagnosis of dengue infection using composite reference criteria: A cross-sectional study from South India. J Vector Borne Dis. 2016;53:30-56.

25. Fletcher J. Choosing a statistic. BMJ 2009; 339:b2702. doi: https://doi.org/10.1136/bmj.b2702

26. Baragundi MC, Vishwanath G, Hanumanthappa AR, Suresh K, Chandrappa NR, Patil CS. Comparative study of blood culture and Staphylococcal coagglutination test in clinically suspected cases of enteric fever. Ind J Med Microbiol 2010; 28 (4): 417-18.

27. Mohanty SK, Ramana KV.Single and unpaired sera tube Widal agglutination test in enteric fever. Saudi J Gastro 2007; 13: 213-15.

28. Porwal A, Bhat S. Antibiotic Resistance Pattern among Enteric Fever Pathogens in a Tertiary Care Centre. Nat J Lab Med. 2016; 5(3): 15-18.

29. Poudel S, Shrestha SK, Pradhan A, apkota B, Mahato M (2014) Antimicrobial Susceptibility Pattern of Salmonella enterica Species in Blood Culture Isolates. Clin Microbial 3:141. doi: 10.4172/23275073.1000141 
30. Yadav S, Sharma M, Aparna, Chaudhary U. Antibiogram of Salmonella serotypes at a tertiary care hospital in North India. World J Pharm Sci 2014; 2(4): 328-330.

31. Gaikwad UN, Rajurkar M. Diagnostic efficacy of Widal slide agglutination test against Widal tube agglutination test in enteric fever. Int $\mathrm{J}$ Med Public Health 2014;4:227-30.

32. Keddy KH, Sooka A, Letsoalo ME, Hoyland G, Chaignat CL, Morrisseye AB. Sensitivity and specificity of typhoid fever rapid antibody tests for laboratory diagnosis at two sub-Saharan African sites. Bull World Health Organ 2011;89:640-47. doi:10.2471/BLT.11.087627

33. Das JC. Laboratory investigation of enteric fever in children; an update. JCMCTA.2007;18(2):37- 42.

34. Olsen SJ, Pruckler J, Bibb W, Thanh NTM, Trinh TM, Minh NT et al. Evaluation of Rapid Diagnostic Tests for Typhoid Fever. J Clin Microbiol 2004; 42(5):1885-89.

doi: 10.1128/JCM.42.5.1885-89.2004

35. Handojo I, Edijanto SP, Probohoesodo MY, Mahartini NN.Comparison of the diagnostic value of local Widal slide test with imported Widal slide test. Southeast Asian J Trop Med Public Health. 2004 ;35(2):366-70.

\author{
Abbreviations: \\ BHI- Brain Heart Infusion Broth \\ CLSI-Clinical and Laboratory Standards Institute \\ Ig- Immunoglobulin \\ LR- Likelihood Ratio \\ NPV-Negative Predictive value \\ PPV-Positive Predictive value \\ RCT-Rapid Card Test \\ WHO-World Health Organisation
}

